\title{
Caladium cv. Florida sweetheart production at different planting depths and sowing dates ${ }^{(1)}$
}

\author{
IBRAR HUSSAIN(2), NOOR UL AMIN(3)
}

\begin{abstract}
Ornamental bulbous crops emergence and yield can be improved by its emergence from soil. The response of Caladium to different planting depths and dates was investigated at Ornamental Horticulture Nursery, Department of Horticulture, The University of Agriculture, Peshawar during the year 2008. Randomized Complete Block Design in a split plot arrangement was used repeated three times. Sowing dates ( $30^{\text {th }}$ March, $15^{\text {th }}$ April and $30^{\text {th }}$ April) were allotted to main plots whereas planting depths $(2.5 \mathrm{~cm}, 5$ $\mathrm{cm}, 7.5 \mathrm{~cm}$ and $10 \mathrm{~cm}$ ) were kept in sub plots. Findings revealed that Caladium tubers sown on $30^{\text {th }}$ March took maximum days to sprouting (33), produced maximum number of sprouts plant ${ }^{-1}(2.21)$, gained maximum tuber size $\left(40.88 \mathrm{~cm}^{3}\right)$ with high tuber yield $\left(5397 \mathrm{~kg} \mathrm{ha}^{-1}\right)$. On the other hand, tubers sown on $30^{\text {th }}$ April took less days to sprouting (20.21), produced less number of sprouts plant ${ }^{-1}(1.53)$, produced small tuber $\left(33.28 \mathrm{~cm}^{3}\right)$ and total tuber yields was also less $\left(4374 \mathrm{~kg} \mathrm{ha}^{-1}\right)$. In case of planting depth, Caladium tubers sown at a depth of $7.5 \mathrm{~cm}$ resulted in maximum plant height $(52 \mathrm{~cm})$, tuber size $\left(41.76 \mathrm{~cm}^{3}\right)$, and tuber yield $(5288$ $\mathrm{kg} \mathrm{ha}^{-1}$ ) while maximum number of tubers plant ${ }^{-1}(1.92)$ was observed at a depth of $10 \mathrm{~cm}$. Tubers sown in $2.5 \mathrm{~cm}$ depth resulted in minimum tuber yield $\left(4538 \mathrm{~kg} \mathrm{ha}^{-1}\right)$ and plant height $(46.56 \mathrm{~cm})$. To maximize vegetative as well as tubers production of Caladium cv. Florida sweet heart, it shall be sown on $30^{\text {th }}$ March with $7.5 \mathrm{~cm}$ depth.
\end{abstract}

Keywords: Caladium hortulanum, tubers production, time of cultivation, planting depth.

\section{RESUMO}

Produção de Caladium cv. Florida sweetheart em diferentes profundidades e datas de plantio

A emergência e o rendimento das culturas bulbosas ornamentais podem ser melhorados pela sua emergência no solo. A resposta do caládio a diferentes profundidades e datas de plantio foi pesquisada no Ornamental Horticulture Nursery, Departamento de Horticultura da Universidade de Agricultura de Peshawar durante o ano de 2008. O desenho de blocos completos randomizados em arranjo de parcelas subdivididas foi repetido três vezes. As épocas de semeadura ( 30 de março, 15 de abril e 30 de abril) foram distribuídas em parcelas principais enquanto as profundidades de plantio $(2,5 \mathrm{~cm}, 5 \mathrm{~cm}, 7,5 \mathrm{~cm}$ e $10 \mathrm{~cm})$ foram mantidas em subparcelas. Os resultados revelaram que os tubérculos de Caladium semeados em 30 de março levaram dias máximos para brotação (33), produziram o número máximo de brotos planta-1 $(2,21)$, ganharam tamanho máximo de tubérculos $\left(40,88 \mathrm{~cm}^{3}\right) \operatorname{com}$ alta produtividade de tubérculos $\left(5.397 \mathrm{~kg} \mathrm{ha}^{-1}\right)$. Por outro lado, tubérculos semeados no dia 30 de abril levaram menos dias para brotar $(20,21)$, produziram menos número de brotos planta-1 $(1,53)$, produziram pequenos tubérculos $\left(33,28 \mathrm{~cm}^{3}\right)$ e a produção total de tubérculos também foi menor $\left(4.374 \mathrm{~kg} \mathrm{ha}^{-1}\right)$. No caso da profundidade de plantio, tubérculos de caládio semeados a $7,5 \mathrm{~cm}$ de profundidade resultaram em altura máxima de plantas $(52 \mathrm{~cm})$, tamanho de tubérculos $\left(41,76 \mathrm{~cm}^{3}\right)$ e rendimento de tubérculos $\left(5.288 \mathrm{~kg} \mathrm{ha}^{-1}\right)$ enquanto número máximo de tubérculos planta ${ }^{-1}(1,92)$ foi observado a uma profundidade de $10 \mathrm{~cm}$. Tubérculos semeados em profundidade de $2,5 \mathrm{~cm}$ resultaram em produtividade mínima de tubérculos $\left(4.538 \mathrm{~kg} \mathrm{ha}^{-1}\right)$ e altura de plantas $(46,56$ $\mathrm{cm})$. Para maximizar a produção vegetativa e tubérculos de caládio cv. Flórida Sweet heart, será semeado no dia 30 de março com $7,5 \mathrm{~cm}$ de profundidade.

Palavras-chave: Caladium hortulanum, produção de tubérculos, tempo de cultivo, profundidade de plantio.

\section{INTRODUCTION}

Caladium (Caladium hortulanum) of Family Araceae commonly known as "Angels wing" is a colorful foliage potted plant or out door bedding plant that can be propagated through seed, tubers and tissue culture. Seed production requires long time and results in seedling's variability and limited only to breeding program. Commercially, caladiums are produced through tubers sown in April and harvested from November to February. Tubers are stored at $65-70{ }^{\circ} \mathrm{F}$ with preferable temperature of $70^{\circ} \mathrm{F}$ at about $75 \%$ relative humidity (CONOVER and POOLE, 1973).

New shoots arise from tubers and each tubers may have 1-5 large prominent and numerous small eyes (HARBAUGH et al., 1979). Caladium performs best in a potting medium containing high peat and organic matter

DOI: http://dx.doi.org/10.14295/oh.v24i4.1194

${ }^{(1)}$ Received in 08/05/2018 and accepted in 25/09/2018

${ }^{(2)}$ Agricultural Research Institute Tarnab, Horticulture section, Agricultural Research Institute Tarnab, Peshawar, Pakistan. *Corresponding author: ibrar horti@yahoo.com

${ }^{(3)}$ The University of Agriculture Peshawar, Department of Horticulture Department of Horticulture, Peshawar, Pakistan.

Licensed by CC BY 4.0 
with optimum water holding capacity. Tubers perform better when sown at a depth of $5.0-7.5 \mathrm{~cm}$ as roots are emerge from the upper side of the tuber with $20-30 \mathrm{~cm}$ apart (ALI, 2012). The nursery growers in Pakistan are not adequately familiar with the production technology of Caladium. Thus growers face serious problems including appropriate planting time and suitable planting depth. The currant study was initiated to locate the best planting time and appropriate depth for optimum production of Caladium tubers under agro climatic conditions of Peshawar, Pakistan and also to study the interaction between sowing dates and depths on foliage growth and tubers production. The findings obtained during this study will not only be of academic interest but also of commercial importance.

\section{MATERIALS AND METHODS}

Caladium cultivars namely Florida Sweetheart were tested to evaluate the effects of various planting depths and sowing dates on the overall performance of Caladium. Plants were raised through tubers obtained from reputed seed/tuber importer at Lahore, Pakistan. Uniform tubers of same size $\left(35 \mathrm{~cm}^{3}\right)$ were grown in mixture containing silt, clay and farm yard manure at 1:1:1 in the field under shade house conditions. They were kept in $60 \%$ shade in a shade house (CONOVER and POOLE, 1973). Randomized Complete Block Design with a split plot arrangement was used in the experiment with three replications having 48 tubers in each replication. Sowing dates $\left(30^{\text {th }}\right.$ March, $15^{\text {th }}$ April and $30^{\text {th }}$ April) were assigned to main plots and sowing depths $(2.5 \mathrm{~cm}, 5 \mathrm{~cm}, 7.5 \mathrm{~cm}$, and $10 \mathrm{~cm})$ were kept in sub plots. The data were statistically analyzed using analysis of variance. Means were compared using LSD test at 0.05 level of probability, when the F-values were significant (JAN et al., 2009).

\section{RESULTS AND DISCUSSION}

\section{Vegetative growth}

Sprouting period/time

Data regarding days taken to sprouting was significantly affected by planting dates, while the effect of planting depth and the interaction between sowing dates and depths were not significant. Maximum days to sprouting (32 days) was taken by the tubers sown on $30^{\text {th }}$ March, followed by the tubers planted on $15^{\text {th }}$ April (25 days), whereas minimum days to sprouting (22 days) were recorded by tubers sown on $30^{\text {th }}$ April (Table 1). This pattern indicates that tubers sown at the end of April took minimum days to sprouting as temperature remained favorable for sprouting. These findings are in close conformity with the results reported by BROWN (2003), He observed that Caladium respond best to sprouting in warm condition as compared to cold. As planting depths are concerned, more time i.e. 27 days to sprouting were taken by tubers sown at $10 \mathrm{~cm}$ depth while fewer days to sprouting i.e. 25 days were taken by tubers sown at a depth of $2.5 \mathrm{~cm}$ (Table 1). This shows that with increasing depth sprouting is delayed. Lee et al. (1997) observed that with increase in planting depth, seeds sprouting were delayed. Galavi et al. (2008) also reported similar findings that sprouting of tubers is appreciably decreased with increasing planting depth.

Table 1. Sprouting period (Days) as affected by sowing dates and planting depths in Caladium.

\begin{tabular}{|c|c|c|c|c|}
\hline \multirow{2}{*}{ Planting depth } & \multicolumn{3}{|c|}{ Sowing dates } & Mean \\
\cline { 2 - 5 } & $30^{\text {th }}$ March & $15^{\text {th }}$ April & $30^{\text {th }}$ April \\
\hline $2.5 \mathrm{~cm}$ & $32.50^{*}$ & $23.58^{*}$ & $17.67^{*}$ & $24.58^{*}$ \\
\hline $5 \mathrm{~cm}$ & 32.58 & 23.83 & 20.50 & 25.64 \\
\hline $7.5 \mathrm{~cm}$ & 35.40 & 23.52 & 21.17 & 26.69 \\
\hline $10 \mathrm{~cm}$ & 31.83 & 28.00 & 21.50 & 27.11 \\
\hline MEAN & $33.08 \mathrm{a}$ & $24.73 \mathrm{ab}$ & $20.21 \mathrm{~b}$ & \\
\hline
\end{tabular}

LSD value at $5 \%$ for Planting dates $=4.028 *$ Do not differ by the LSD test at $5 \%$ of error probability

\section{Number of sprouts plant ${ }^{-1}$}

Production of sprouts is one of the key objectives of Caladium growers as they are mean of propagation and costly market item. It was seen that maximum number of sprouts plant ${ }^{-1}$ (2.21) was recorded in tubers sown on $30^{\text {th }}$ March, followed by tubers sown on $30^{\text {th }}$ April (1.65) while tubers sown on $15^{\text {th }}$ April resulted in minimum number of sprouts plant ${ }^{-1}(1.53)$. In case of planting depth, insignificantly higher number of sprouts plant ${ }^{-1}$ (2.5) was recorded by tubers sown at a depth of 7.5 $\mathrm{cm}$, while lower number of sprouts plant ${ }^{-1}$ (1.61) was noted at $5 \mathrm{~cm}$ depth (Table 2). The present results are in contrast to those reported by Negb et al. (1989), who observed that number of buds sprouted from shallow planted bulbous plant is significantly higher than from deep planted. 
Table 2. Number of sprout plant ${ }^{-1}$ as affected by sowing dates and planting depths in Caladium.

\begin{tabular}{|c|c|c|c|c|}
\hline \multirow{2}{*}{ Planting depth } & \multicolumn{3}{|c|}{ Sowing dates } & Mean \\
\hline $2.5 \mathrm{~cm}$ & $30^{\text {th }}$ March & $15^{\text {th }}$ April & $30^{\text {th }}$ April \\
\hline $5 \mathrm{~cm}$ & $1.83^{*}$ & $2.00^{*}$ & $1.75^{*}$ & $1.86^{*}$ \\
\hline $7.5 \mathrm{~cm}$ & 2.00 & 1.42 & 1.42 & 1.61 \\
\hline $10 \mathrm{~cm}$ & 2.42 & 1.64 & 1.55 & 1.87 \\
\hline MEAN & 2.58 & 1.55 & 1.42 & 1.85 \\
\hline
\end{tabular}

LSD value at $5 \%$ for Planting dates $=0.12 *$ Do not differ by the LSD test at $5 \%$ of error probability

\section{Plant height $(\mathrm{cm})$}

Table 3 indicates that planting depths has significant effect on plant height while the effect of sowing dates as well as interaction between the two factors was found insignificant. Findings revealed that maximum plant height $(49.42 \mathrm{~cm})$ was attained by the tuber sown on $30^{\text {th }}$ March, while minimum plant height $(48.83 \mathrm{~cm})$ was attained by tubers sown on $15^{\text {th }}$ and $30^{\text {th }}$ April respectively. Planting depths significantly affected plant height as maximum plant height $(52 \mathrm{~cm})$ was observed in tubers sown at a depth of 7.5 $\mathrm{cm}$, trailed by $5 \mathrm{~cm}$ depth $(49.22 \mathrm{~cm})$, while minimum plant height $(46.56 \mathrm{~cm})$ was accomplished by the tubers sown at a depth of $2.5 \mathrm{~cm}$. The results of current studies are inline with those reported by Wolf et al. (1990) who observed that high temperatures and long days enhanced plant height and number of leaves. They further reported that tubers planted in the late March produced the tallest plants. The results are also in line with Lee et al. (1997) who observed the best growth in term of plant height and number of leaves obtained from the tubers planted at a depth of $6 \mathrm{~cm}$.

Table 3. Plant height $(\mathrm{cm})$ as affected by sowing dates and planting depth in Caladium.

\begin{tabular}{|c|c|c|c|c|}
\hline \multirow{2}{*}{ Planting depth } & \multicolumn{3}{|c|}{ Sowing dates } & Mean \\
\hline $2.5 \mathrm{~cm}$ & $30^{\text {th }}$ March & $15^{\text {th }}$ April & $30^{\text {th }}$ April \\
\hline $5 \mathrm{~cm}$ & $46.00^{*}$ & $47.33^{*}$ & $46.33^{*}$ & $46.56 \mathrm{c}$ \\
\hline $7.5 \mathrm{~cm}$ & 52.00 & 47.33 & 48.33 & $49.22 \mathrm{~b}$ \\
\hline $10 \mathrm{~cm}$ & 52.00 & 52.00 & 52.00 & $52.00 \mathrm{a}$ \\
\hline MEAN & 47.67 & 48.67 & 48.67 & $48.33 \mathrm{~b}$ \\
\hline
\end{tabular}

LSD value at $5 \%$ for Planting depths $=1.67 *$ Do not differ by the LSD test at $5 \%$ of error probability

\section{Reproductive growth:}

\section{Tuber weight plant ${ }^{1}$}

Tuber weight plant $^{-1}$ was significantly affected by sowing dates and planting depths whereas the interaction between the two under test factors was non significant. Table 4 shows that maximum tuber weight plant ${ }^{-1}$ (48.58 g) was observed in tubers sown on $30^{\text {th }}$ March, followed by $15^{\text {th }}$ April (44.62 g), while sowing on $30^{\text {th }}$ April resulted in minimum tuber weight plant $^{-1}(39.36 \mathrm{~g})$. Maximum tuber weight plant $^{-1}(47.59 \mathrm{~g})$ was recorded in tubers sown at a depth of $7.5 \mathrm{~cm}$, whilst minimum tubers weight plant $^{-1}$ (40.80 g) was observed at $2.5 \mathrm{~cm}$ depth (Table 4). The same pattern was reported by Lorenz (2003) who observed that best sowing depth for enhancing tuber production was 4-6 inches. The interaction between sowing dates and planting depths was not significant, however maximum tuber weight $\operatorname{plant}^{1}(58.20 \mathrm{~g})$ was recorded in tubers sown on $30^{\text {th }}$ March at a depth of $7.5 \mathrm{~cm}$, while minimum tuber weight plant $^{-1}$ (37.92 g) was observed in tubers sown on $30^{\text {th }}$ April at a depth of $5.0 \mathrm{~cm}$. 
Table 4. Tuber weight (g) plant ${ }^{-1}$ as affected by sowing dates and planting depths in Caladium.

\begin{tabular}{|c|c|c|c|c|}
\hline \multirow{2}{*}{ Planting depth } & \multicolumn{3}{|c|}{ Sowing dates } & Mean \\
\hline $2.5 \mathrm{~cm}$ & $30^{\text {th }}$ March & $15^{\text {th }}$ April & $30^{\text {th }}$ April \\
\hline $5 \mathrm{~cm}$ & $41.56^{*}$ & $40.67^{*}$ & $40.17^{*}$ & $40.80 \mathrm{~b}$ \\
\hline $7.5 \mathrm{~cm}$ & 48.54 & 47.82 & 37.92 & $44.76 \mathrm{ab}$ \\
\hline $10 \mathrm{~cm}$ & 58.20 & 44.33 & 40.25 & $47.59 \mathrm{a}$ \\
\hline MEAN & 46.00 & 45.67 & 39.13 & $43.60 \mathrm{ab}$ \\
\hline
\end{tabular}

LSD value at $5 \%$ for Planting dates $=6.720$, Planting depths $=4.57 *$ Don't differ by the LSD test at $5 \%$ of error probability

\section{Tuber size $\left(\mathrm{cm}^{3}\right)$}

The analysis of (Table 5) indicates that tuber size was significantly affected by planting dates, while the effect of planting depths as will as interaction between the two factors was not significant. Mean value of the data showed that higher tuber size $\left(40.88 \mathrm{~cm}^{3}\right)$ was produced in tubers sown on $30^{\text {th }}$ March, followed by the tubers sown on $15^{\text {th }}$ April $\left(35.77 \mathrm{~cm}^{3}\right)$, whereas minimum tuber size $(33.29$ $\mathrm{cm}^{3}$ ) was recorded in tubers sown on $30^{\text {th }}$ April. In case of planting depths, a non significant response was observed on tuber size, however higher tuber size was recorded in plants sown $7.5 \mathrm{~cm}$ deep $\left(41.76 \mathrm{~cm}^{3}\right)$. Current studies further revealed that minimum tuber size $\left(33.70 \mathrm{~cm}^{3}\right)$ was recorded in plants sown at a depth of $10 \mathrm{~cm}$. The same pattern reported by David (1987) who concluded that increasing sowing depth increases tuber size.

Table 5. Tuber size $\left(\mathrm{cm}^{3}\right)$ as affected by sowing dates and planting depths in Caladium.

\begin{tabular}{|c|c|c|c|c|}
\hline \multirow{2}{*}{ Planting depth } & \multicolumn{3}{|c|}{ Sowing dates } & Mean \\
\hline $2.5 \mathrm{~cm}$ & $30^{\text {th }}$ March & $15^{\text {th }}$ April & $30^{\text {th }}$ April \\
\hline $5 \mathrm{~cm}$ & $46.25^{*}$ & $32.00^{*}$ & $27.43^{*}$ & $35.23 \mathrm{~b}$ \\
\hline $7.5 \mathrm{~cm}$ & 38.88 & 34.58 & 34.23 & $35.89 \mathrm{~b}$ \\
\hline $10 \mathrm{~cm}$ & 43.75 & 39.83 & 41.71 & $41.76 \mathrm{a}$ \\
\hline MEAN & 34.63 & 36.67 & 29.80 & $33.70 \mathrm{~b}$ \\
\hline
\end{tabular}

LSD value at $5 \%$ for Planting dates $=5.08$, Planting depths $=3.414 *$ Don't differ by the LSD test at $5 \%$ of error probability

\section{Number of tuber plant ${ }^{-1}$}

Planting depth had positive effect on tuber production, while planting date and interaction between the two factors was insignificant. However, higher number of tubers plant ${ }^{-1}(1.85)$ was observed in tubers sown on $30^{\text {th }}$ March, whereas sowing on $30^{\text {th }}$ April resulted in lowest number of tuber plant ${ }^{-1}(1.73)$. In case of planting depth, higher number of tuber plant ${ }^{-1}(1.92)$ was recorded in tuber sown at $10 \mathrm{~cm}$ depth, followed by $2.5 \mathrm{~cm}$ depth (1.89) which were statistically at same level with all the three planting depth except $5 \mathrm{~cm}$ (1.53). These results are in line with Barry et al, (2001) who stated that planting depth of $5.0 \mathrm{~cm}$ was suitable for enhance tuber production. 
Table 6. Number of tubers plant ${ }^{-1}$ as affected by sowing dates and planting depths in Caladium.

\begin{tabular}{|c|c|c|c|c|}
\hline \multirow{2}{*}{ Planting depth } & \multicolumn{3}{|c|}{ Sowing dates } & \\
\hline & $30^{\text {th }}$ March & $15^{\text {th }}$ April & $30^{\text {th }}$ April & $1.89 \mathrm{a}$ \\
\hline $2.5 \mathrm{~cm}$ & $2.00^{*}$ & $1.92^{*}$ & $1.75^{*}$ & $1.53 \mathrm{~b}$ \\
\hline $5 \mathrm{~cm}$ & 1.50 & 1.58 & 1.50 & $1.78 \mathrm{a}$ \\
\hline $7.5 \mathrm{~cm}$ & 2.00 & 1.50 & 1.83 & $1.92 \mathrm{a}$ \\
\hline $10 \mathrm{~cm}$ & 1.92 & 2.00 & 1.83 & 1.73 \\
\hline
\end{tabular}

LSD value at $5 \%$ for Planting depths $=0.243 *$ Don’t differ by the LSD test at $5 \%$ of error probability

Table 7 indicates that tubers yield was significantly affected by both the planting depths and planting dates while interaction between the two factors was insignificant. Highest number of tuber yield $\left(5397 \mathrm{~kg} \mathrm{ha}^{-1}\right)$ was observed in tubers sown on $30^{\text {th }}$ March, followed by $15^{\text {th }}$ April (4958 $\left.\mathrm{kg} \mathrm{ha} \mathrm{h}^{-1}\right)$, whereas tubers sown on $30^{\text {th }}$ April resulted in lowest number of tuber yield (4374 $\left.\mathrm{kg} \mathrm{ha}^{-1}\right)$. These results are in line with those reported by Kaukoranta and Hakala
(2008) who stated that earlier sowing of spring tuber crop had positive affect on yield potential of tubers. In case of planting depths, mean value of the data revealed that greatest tuber yield $\left(5288 \mathrm{~kg} \mathrm{ha}^{-1}\right)$ was recorded in tubers sown at $7.5 \mathrm{~cm}$ depth, followed by planting depth of 5.0 $\mathrm{cm}\left(4973 \mathrm{~kg} \mathrm{ha}^{-1}\right)$, which were statistically at par with both planting depth at $2.5 \mathrm{~cm}$ and $10.0 \mathrm{~cm}$. planting depth in 2.5 $\mathrm{cm}$ resulted in lowest tuber yield $\left(4532 \mathrm{~kg} \mathrm{ha}^{-1}\right)$.

Table 7. Tuber yield $\mathrm{kg} \mathrm{ha}^{-1}$ as affected by sowing dates and planting depth in Caladium.

\begin{tabular}{|c|c|c|c|c|}
\hline \multirow{2}{*}{ Planting depth } & \multicolumn{3}{|c|}{ Sowing dates } & Mean \\
\hline & $30^{\text {th }}$ March & $15^{\text {th }}$ April & $30^{\text {th }}$ April \\
\hline $5 \mathrm{~cm}$ & $4617^{*}$ & $4519^{*}$ & $4463^{*}$ & $4533 \mathrm{~b}$ \\
\hline $5 \mathrm{~cm}$ & 5394 & 5313 & 4213 & $4973 \mathrm{a}$ \\
\hline $7.5 \mathrm{~cm}$ & 6467 & 4926 & 4472 & $5288 \mathrm{a}$ \\
\hline $10 \mathrm{~cm}$ & 5111 & 5074 & 4347 & $4844 \mathrm{ab}$ \\
\hline MEAN & $5397 \mathrm{a}$ & $4958 \mathrm{ab}$ & $4374 \mathrm{~b}$ & \\
\hline
\end{tabular}

LSD value at $5 \%$ for Planting dates $=508.4$, Planting depths $=746.6 *$ Do not differ by the LSD test at $5 \%$ of error probability

\section{CONCLUSIONS}

Caladium tubers sown on 30th March resulted in maximum number of tubers, weight plant $^{-1}$ and tuber yield. On the other hand, tuber sown at a depth of 7.5 $\mathrm{cm}$ produced significantly higher tuber number, tuber size and tuber yield. The trend in current study shows that $30^{\text {th }}$ March is the best sowing time for obtaining maximum yield. Similarly maximum plant height, tuber size, tuber weight plant ${ }^{-1}$ and tuber yield may be obtained when Caladium tubers sown at a depth of $7.5 \mathrm{~cm}$. The present study recommends that Caladium tuber be sown at the end of March at a depth of $7.5 \mathrm{~cm}$ for quality tubers production. It is additionally recommended that further research work on spacing and nitrogen requirements need to be initiated to authenticate current findings which may help in formulating general recommendations for Caladium growers.

\section{ACKNOWLEDGEMENTS}

The author thanks The University of Agriculture and Higher Education Commission for financial support.

\section{AUTHORS CONTRIBUTIONS}

I.H. D0000-0002-5784-7902: Conceived and designed the experiments: performed the experiments and wrote the paper. N.A.: analyzed the data, Contributed reagents/ materials/ analysis tools. 


\section{REFERENCES}

ALI, T.; RAZIEH, A. Effect of Planting Depth, bulb Size and their interactions on growth and flowering of tuberose (Polianthes tuberosa L.). American-Eurasian Journal. of Agriculture and Environmental Sciences. v.12, n.11, p.1452-1456, 2012. DOI: 10.5829/idosi. aejaes.2012.12.11.1828.

BARRY, P.; CLANCY P.C.; MOLLOY M. The effect of seed size and planting depth on the yield of seed potatoes grown from minitubers. Irish Journal of Agricultural and Food Research, v.40, p.71-81, 2001.

BROWN DALLAS. Worked on different aspects affected due to proper planting time of Caladium, County Master Gardener, 2003.

CONOVER, C.A.; POOLE, R.T. Influence of shade level and soil temperature on forcing of caladium bicolor. Florida State Horticulture.v.86, p.369-372, 1973.

DAVID, F.S. Tuber Size and planting depth influence on growth of Potamogetion pectinulate. Journal of American Midland Naturalist. v.118, p.77-84, 1987.

GALAVI, M.; M. SOLOKI.; MOUSAVI, S. R.; ZIYAIE, M. Effect of planting depth and soil summer temperature control on growth and yield of Saffron. Asian Journal of Plant Sciences, v.7, n.8, p.747-751. 2008. DOI: https:// scialert.net/abstract/?doi=ajps.2008.747.751.
JAN, M.; SHAH, T.P.; HOLLINGTON, P.A.; KHAN, M.J.; SOHAIL, Q. Agriculture Research: design and analysis, a Monograph. Peshawar, Pakistan: NWFP Agricultural University, 2009. 24p.

KAUKORANTA, T.; HAKALA, K. Impact of spring warming on sowing times of cereal, potato and sugar beet in Finland. Agricultural and Food Science, v.17, p.165176, 2008.

LEE, J.J.; JEONG, J.S.; KIM, D. K.; KWON, S. W.; KIM, J.C. Effect of planting depth on the growth and flowering in summer cultivation of cut freesia. Korean Society of Horticultural Sciences, v.38, n.1, p.77-80, 1997.

LORENZ, O.A. Effect of planting potato tubers at different planting depth. Journal of Potato Research. v.22, p.343$349,2003$.

NEGB, M.; DAGAN, B.; DROR, A.; BASKER, D. Growth, flowering, vegetative reproduction, and dormancy in the saffron crocus (Crocus sativus L.). Israel Journal of Botany. v.39, p.95-113, 1989.

WOLF, S.; MARANI, A.; RUDICH, J. Effect of temperature on carbohydrate metabolism in potato plants. Journal of Experimental Botany, v.42, n.5, p.619-625, 1998. 